\title{
EFFECT OF COIR FIBRES ON THE COMPACTION AND UNCONFINED COMPRESSIVE STRENGTH OF BENTONITE-LIME-GYPSUM MIXTURE
}

\author{
Vidya TILAK B. ${ }^{1}$, Rakesh Kumar DUTTA ${ }^{1 *}$, Bijayananda MOHANTY ${ }^{1}$
}

\begin{abstract}
This paper presents the effect of coir fibres on the compaction and unconfined compressive strength of a bentonite-lime-gypsum mixture. The coir fiber content varied from 0.5 to $2 \%$. The results indicated that the dry unit weight and the optimum moisture content of a bentonite - lime mix increased with the addition of gypsum. The unconfined compressive strength of the bentonite increased with the increase in the lime content up to 8 $\%$. Beyond $8 \%$, the unconfined compressive strength decreased. The dry unit weight of the reference mix decreased, and the optimum moisture content increased with the addition of coir fibre. The unconfined compressive strength of the bentonite $+8 \%$ lime mix increased up to $4 \%$ with the gypsum. Beyond $4 \%$, the unconfined compressive strength decreased. The unconfined compressive strength of the reference mix increased with the addition of coir fibre up to a fibre content of $1.5 \%$. The unconfined compressive strength of the reference mix-coir fibre composite was less in comparison to the reference mix. The unconfined compressive strength of the bentonite increased with the addition of lime and gypsum and with the increase in the curing period. The improvement in the post-peak region was better for the reference mix with reinforced coir fibres as compared to the unreinforced reference mix. The improved post-peak behaviour of the bentonite-lime-gypsum-coir fibre mixture could boost the construction of temporary roads on such problematic soils. Further, its use will also provide an environmental motivation for providing a means of consuming large quantities of coir fibres.
\end{abstract}

\section{INTRODUCTION}

Expansive soils pose serious problems for temporary roads constructed over them in terms of differential settlements, poor strength, and high compressibility, especially during a rainy season. Several states in India have vast deposits of expansive soils. The current approach adopted to treat such territories is to modify the properties

\section{Address}

1 Department of Civil Engineering, National Institute of Technology, Hamirpur - 177005, Himachal Pradesh, India

Corresponding author: rakeshkdutta@yahoo.com

Key words

- Bentonite

- lime,

- gypsum,

- unconfined compressive strength,

- coir fibre. 
therefore gaining in popularity as they too are biodegradable in nature and do not cause any environmental problems. In the present paper, an attempt has been made to study the compaction and unconfined compressive strength of a bentonite-lime-gypsum mixture reinforced with coir fibres for possible use in improving soil.

\section{BACKGROUND}

Many researchers in the past have demonstrated the effectiveness of including fibres in soil (Hoare, 1979; Ranjan et al., 1994; Michlowski and Cermak, 2003; Andersland and Khattack, 1979; Maher and Ho, 1994; Al Wahab and El-Kedrah, 1995; Nataraj and McManis, 1997; Zeigler et al., 1998; Feuerharmel, 2000; Kumar and Tabor, 2003; Casagrande et al., 2006). Prasad et al, (1983) reported that the removal of lignin, hemicellulose, silica, and pith from coir fibres results in a better interaction with soil. Mwasha (2009) reported that coir fibres have good strength characteristics and are resistant to bio-degradation over a long period of time. Sebastain et al. (2011) reported that randomly distributed fibres offer strength isotropy and limit potential planes of weakness that could otherwise possibly develop parallel to a reinforcement oriented in reinforced soils. Lekha and Sreedevi (2006) conducted a compaction study on soil reinforced with coir fibres and reported changes in the optimum moisture content and maximum dry unit weight. Their study reveals that the optimum moisture content increases and the dry unit weight decreases with an increase in coir fibre content. Dutta et al (2013) reported the effect of coir fibres on the compaction behaviour of clay. The results of this study indicated that the optimum moisture content and the maximum dry unit weight of clay reinforced with coir fibres increases and decreases respectively with the increase in the fibre content.

Maher and Ho (1994) reported that the peak compressive strength of kaolinite clay was increased by the inclusion of randomly distributed paper pulp fibres. Rao and Balan (2000) reported a significant gain in the strength parameters and stiffness of sand with the inclusion of coir fibres. Banerjee et al. (2002) investigated the dimensional and mechanical properties of coir fibres as a function of fibre length. Saran (2006) advocated the use and consideration of locally available natural fibres such as coir, etc., in designs in order to minimize the cost of ply soil. Casagrande et al. (2006) reported that the inclusion of randomly distributed coir fibres increased the peak shear strength of bentonite. The use of coir fibres as a soil reinforcement is a cost-effective method of improving soil in a country like India as they are cheap and locally available. Babu and Vasudevan (2008) reported that the strength and stiffness of tropical soil were increased with the inclusion of about 1-2\% discrete coir fibres by weight. Ramesh et al. (2010) reported that the unconfined compressive strength of black cotton soil reinforced with bitumen-coated coir fibres showed a marginal variation in strength as compared to uncoated coir fibres. Dasaka and Sumesh (2011) reported that varying the length of coir fibres and content in soil results in an improvement in the strength characteristics. Dutta et al. (2012) conducted unconfined compressive strength tests on clay reinforced with coir fibres and observed a considerable increase in unconfined compressive strength. Hejazi et al. (2012) reviewed the use of natural and synthetic fibres as construction and building materials and reported that fibre reinforcement improves the strength and stiffness of composite soil. Nevertheless, hardly any literature is available to study the effect of coir fibres on the compaction and unconfined compressive strength of a bentonite-lime-gypsum mixture. The present study attempts to fill this gap. In the present work, the effect of coir fibres on the compaction and unconfined compressive strength of a bentonite-lime-gypsum mixture is studied for possible use in improving soil.

\section{MATERIAL USED AND EXPERIMENTAL PROCEDURE}

Commercially available bentonite was used in this study. The physical and engineering properties of the bentonite are given in Table 1 . Hydrated lime, gypsum and coir fibres were procured from a local market in Hamirpur, Himachal Pradesh, India. The specific gravity of the lime, gypsum and coir fibre was $2.37,2.89$ and 1.2, respectively. The properties of the coir fibres are reported by Banerjee et al. (2002) and are shown in Table 2.

Tab. 1 Physical and Engineering Properties of Bentonite.

\begin{tabular}{lc}
\hline \multicolumn{1}{c}{ Property } & Value \\
\hline Specific gravity & 2.30 \\
Liquid limit & 220 \\
Plastic limit & 39.74 \\
Optimum moisture content $(\%)$ & 27.98 \\
Maximum dry density $\left(\mathrm{kN} / \mathrm{m}^{3}\right)$ & 13.95 \\
Type & $\mathrm{CH}$ \\
\hline
\end{tabular}

Tab. 2 Properties of coir fibres (after Banerjee et al., 2002).

\begin{tabular}{lc}
\hline \multicolumn{1}{c}{ Property } & Fibres $<100 \mathrm{~mm}$ in length \\
\hline Breaking load, $\mathrm{N}$ & 217.8 \\
Tenacity (cN/tex) & 11.5 \\
Modulus (Initial) (cN/tex) & 85.9 \\
Modulus offset) (cN/tex) & 9.5 \\
Breaking extension, \% & 41.7 \\
Energy to break (Joules) & 0.0062 \\
Thickness in $1 / 100^{\text {th }} \mathrm{mm}$ & 13.57 \\
Linear density (tex) & 18.9 \\
\hline
\end{tabular}

The standard proctor compaction tests were conducted as per IS 2720-Part-VII (1980) on bentonite-lime and bentonite-lime-gypsum mixtures by varying the content of the lime and gypsum from 2 to 10 $\%$ and 0.5 to $8 \%$, respectively. Water was added as needed to facilitate the mixing and compaction process.

For the unconfined compressive strength tests, a metallic mould with an inner diameter of $38 \mathrm{~mm}$ and a length of $76 \mathrm{~mm}$, with additional detachable collars at both ends, was used to prepare the cylindrical specimens. The required quantities of bentonite, lime, gypsum and coir fibres were mixed, and water corresponding to the optimum moisture content was added. The mix was placed inside the mould. To ensure a uniform compaction, the specimens were statically compressed from both ends till they just reached the dimensions of the mould. Then the specimens were extracted with a hydraulic jack and placed in airtight polythene bags, which were placed inside a dessicator for curing for $3,7,14$ and 28 days. The specimens were taken out of the dessicator and polythene bag after the desired curing period and tested for their unconfined compressive strength using a strain rate of $1.2 \mathrm{~mm} / \mathrm{min}$. The unconfined compressive strength tests were conducted as per IS 2720-Part-X (1991). 


\section{RESULTS}

\subsection{Compaction}

The dry unit weight and moisture content curves for the bentonite with varying percentages of lime are shown in Fig. 1(a). Fig. 1 (a) reveals that the maximum dry unit weight for the bentonite was $13.95 \mathrm{kN} /$ $\mathrm{m}^{3}$, which decreased to $13.72 \mathrm{kN} / \mathrm{m}^{3}, 13.45 \mathrm{kN} / \mathrm{m}^{3}, 13.37 \mathrm{kN} / \mathrm{m}^{3}, 13.34$ $\mathrm{kN} / \mathrm{m}^{3}$ and $13.29 \mathrm{kN} / \mathrm{m}^{3}$ respectively, with the addition of 2, 4, 6, 8 and $10 \%$ lime. The decrease in the dry unit weight is attributed to the fact that lime reacts quickly with bentonite, resulting in a Base Exchange aggregation and flocculation, which lead to an increase in the void ratio of the mixture and a decrease in the dry unit weight of the bentonite-lime mixture. Fig. 1 (a) further reveals that the optimum moisture content of the bentonite was $27.98 \%$, which increased to $29.88 \%$, $31.71 \%, 31.90 \%, 32.40 \%$ and $33.20 \%$, respectively, with the addition of 2, 4, 6, 8 and $10 \%$ lime. This increase in optimum moisture

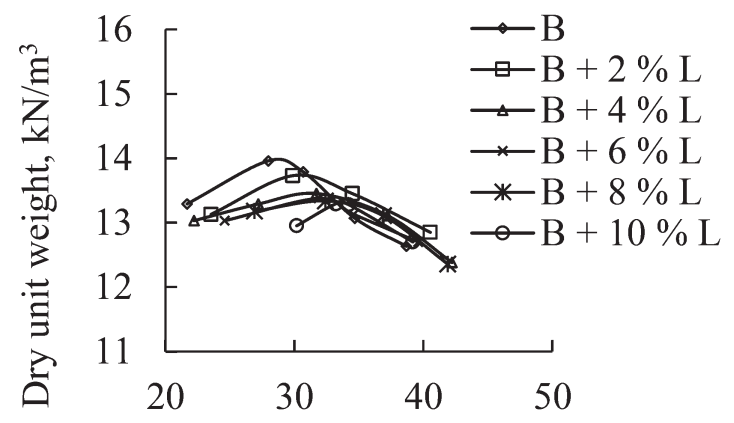

(a)

Moisture content, $\%$

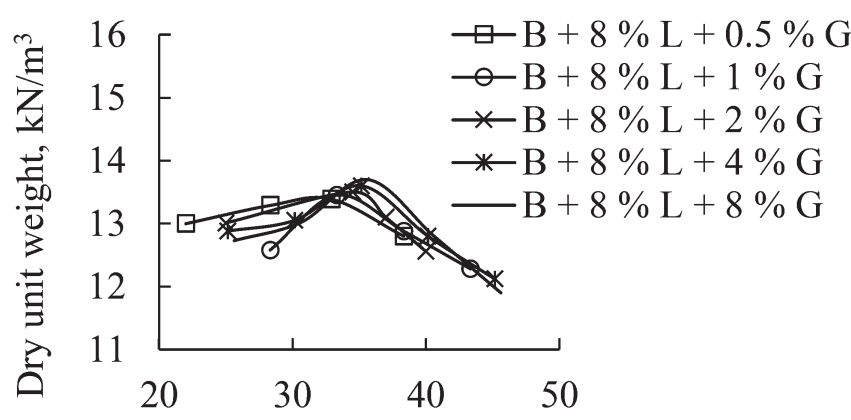

(b)

Moisture content, \%

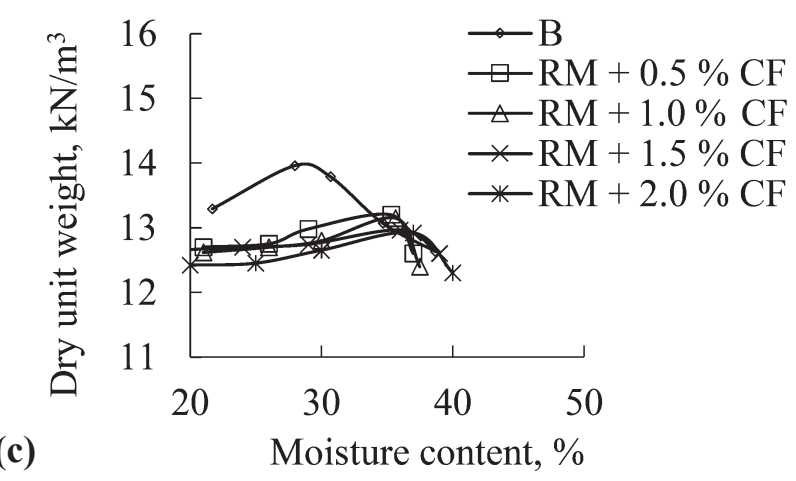

Fig. 1 Compaction curves for (a) bentonite with varying percentages of lime (b) bentonite $+8 \%$ lime with varying percentages of gypsum (c) bentonite $+8 \%$ lime $+4 \%$ gypsum with varying percentages of coir fibres. content is attributed to the fact that additional water was held within the flocs resulting from the flocculation due to the lime reaction. These observations are in agreement with Kumar et al. (2007), where the effect of lime on the compaction behaviour of black cotton soil was reported.

In order to determine the optimum mix of bentonite and lime, it was decided to conduct unconfined compressive strength tests. A similar procedure was adopted by Kumar et al (2007) for fixing an optimum mix with lime. The unconfined compressive strength of the bentonite cured for 3 days was $154.25 \mathrm{kPa}$, which increased to 248.25 $\mathrm{kPa}, 325.25 \mathrm{kPa}, 387.47 \mathrm{kPa}$, and $442.77 \mathrm{kPa}$ with the addition of 2 , $4,6,8 \%$ lime and decreased to $306.54 \mathrm{kPa}$ with the addition of $10 \%$ lime during the same curing period. A similar trend was observed for other curing periods of 7, 14 and 28 days, and the results are shown
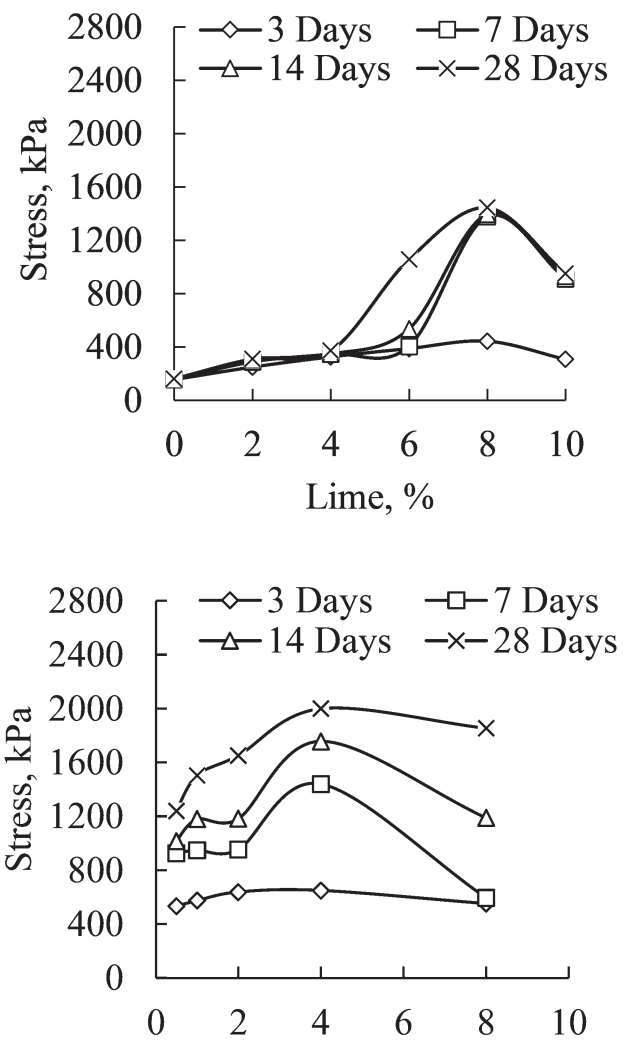

(b)

Gypsum, \%

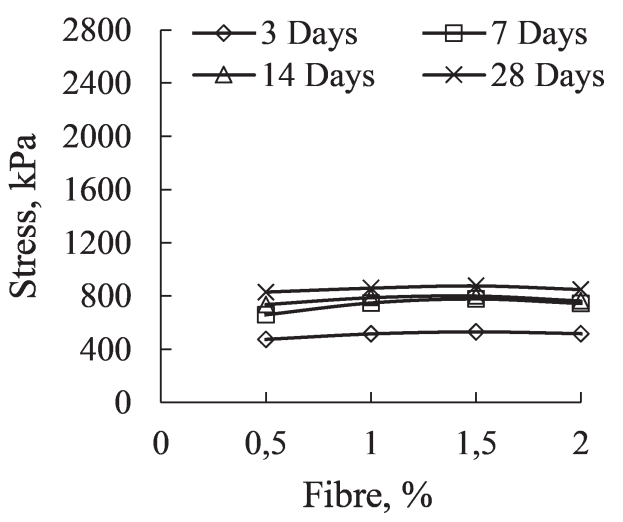

Fig. 2 Variations of unconfined compressive strength of (a) bentonite with varying percentages of lime and curing periods (b) bentonite $+8 \%$ lime with varying percentages of gypsum and curing periods (c) bentonite $+8 \%$ lime $+4 \%$ gypsum with varying percentages of coir fibre and curing periods. 
in Fig. 2 (a). Therefore, on the basis of the results shown in Fig. 2 (a), a mix of bentonite $+8 \%$ lime was chosen for studying the compaction behaviour by varying the amount of gypsum. The results of the dry unit weight and moisture content for the bentonite $+8 \%$ lime with varying percentages of gypsum are shown in Fig. 1(b). Fig. 1 (b) reveals that the maximum dry unit weight for the bentonite $+8 \%$ lime was $13.34 \mathrm{kN} / \mathrm{m}^{3}$, which increased to $13.39 \mathrm{kN} / \mathrm{m}^{3}, 13.45 \mathrm{kN} / \mathrm{m}^{3}$, $13.50 \mathrm{kN} / \mathrm{m}^{3}, 13.60 \mathrm{kN} / \mathrm{m}^{3}$ and $13.70 \mathrm{kN} / \mathrm{m}^{3}$ respectively with the addition of $0.5,1,2,4$ and $8 \%$ gypsum. The increase in dry unit weight is attributed to the fact that the gypsum fills up the void spaces left after the quick reaction of the bentonite with the lime, resulting in the Base Exchange aggregation and flocculation.

Fig. 1 (b) further reveals that the optimum moisture content of the bentonite $+8 \%$ lime was $32.40 \%$, which increased to $32.90 \%, 33.33$ $\%, 34.50 \%, 35.15 \%$ and $35.63 \%$ respectively with the addition of $0.5,1,2,4$ and $8 \%$ gypsum. The effect of the addition of $4 \%$ gypsum to the bentonite $+8 \%$ lime is to produce a greater maximum dry unit weight and optimum moisture content. These observations are in agreement with Wild et al. (1996), where the compaction behaviour was reported concerning lime-stabilized kaolinite in the presence of sulphates. Thus, from the above discussion, it is concluded that the dry unit weight and optimum moisture content of bentonite $+8 \%$ lime increased with the addition of $4 \%$ gypsum.

In order to decide the optimum mix of bentonite-lime-gypsum, it was decided to conduct unconfined compressive strength tests. A similar procedure was adopted by Kumar et al (2007) for fixing the optimum mix with lime. The unconfined compressive strength of the bentonite + $8 \%$ lime cured for 3 days was $442.77 \mathrm{kPa}$, which increased to 531.79 $\mathrm{kPa}, 573.30 \mathrm{kPa}, 637.18 \mathrm{kPa}$ and $648.72 \mathrm{kPa}$ with the addition of $0.5,1$, 2 , and $4 \%$ gypsum and decreased to $551.25 \mathrm{kPa}$ with the addition of 8 $\%$ gypsum during the same curing period. A similar trend was observed for other curing periods in 7, 14 and 28 days, and the results are shown in Fig. 2 (b). Therefore, on the basis of the results shown in Fig. 2 (b), a reference mix of bentonite $+8 \%$ lime $+4 \%$ gypsum was chosen for further study. The compaction curves for the reference mix mixed with varying percentages of coir fibres are shown in Fig. 1 (c).

This figure reveals that the maximum dry unit weight for the reference mix was $13.60 \mathrm{kN} / \mathrm{m} 3$, which decreased to $13.20 \mathrm{kN} / \mathrm{m} 3$, $13.15 \mathrm{kN} / \mathrm{m} 3,12.96 \mathrm{kN} / \mathrm{m} 3$, and $12.92 \mathrm{kN} / \mathrm{m} 3$ respectively with the addition of $0.5,1,1.5$ and $2 \%$ coir fibres. The decrease in the dry unit weight of the reference mix with the increase in the coir fiber can perhaps be attributed to the lower specific gravity of the coir fibres in comparison to the reference mix. The optimum moisture content of the reference mix was $35.15 \%$, which increased to $35.30 \%, 35.65 \%$, $36 \%$ and $37 \%$ respectively as is evident in Fig. 1(c) with the addition of $0.5,1,1.5$ and $2 \%$ coir fibres. This increase in optimum moisture content with the increase in the coir fibre content is attributed to the water absorption tendency of coir fibres.

In order to decide the optimum mix of the bentonite-lime-gypsum-coir fibres, it was decided to conduct unconfined compressive strength tests. The unconfined compressive strength of the reference mix cured for 3 days was $648.72 \mathrm{kPa}$, which changed to $476.00 \mathrm{kPa}$, $516.23 \mathrm{kPa}, 531.52 \mathrm{kPa}$ and $518.15 \mathrm{kPa}$ respectively with the addition of $0.5,1,1.5$ and $2 \%$ coir fibre at the same curing period. A similar trend was observed for other curing periods of 7, 14 and 28 days, and the results are presented in Fig. 2 (c).

\subsection{Unconfined Compressive Strength}

The axial stress-strain curve of the bentonite with varying percentages of lime and cured for 3, 7, 14, and 28 days respectively is shown in Fig. 3 (a). Fig. 3 (a) also contains the axial stress-strain curves for the bentonite cured for 3, 7, 14 and 28 days respectively.
Fig. 3 (a) reveals that the axial stress at the failure of the bentonite does not appreciably improve with an increase in the curing period. For example, the axial stress at the failure of the bentonite cured for 3 days was $154.25 \mathrm{kPa}$, which marginally increased to $154.263 \mathrm{kPa}$ , $158.89 \mathrm{kPa}$ and $162.03 \mathrm{kPa}$ respectively after 7, 14 and 28 days of curing. The improvement in unconfined compressive strength with the curing period is within the experimental error. Hence, for all practical purposes it is concluded that there is no change in the unconfined compressive strength of the bentonite with the curing period.

A further examination of Fig. 3 (a) reveals that the axial stress at failure increased with the increase in the curing period. For example, for the bentonite $+2 \%$ lime mix cured for 3 days, the axial stress at failure was $248.25 \mathrm{kPa}$, which increased to $287.51 \mathrm{kPa}, 303.60 \mathrm{kPa}$ and $311.01 \mathrm{kPa}$ with the increase in the curing period to 7,14 and 28 days respectively. The increase in the axial stress at failure with the curing period is attributed to the pozzolanic reactions of the lime with the bentonite, leading to an increase in the axial stress at failure. A similar trend of an increase in the axial stress at failure was observed for a lime content of $4,6,8$ and $10 \%$.

A close examination of Fig. 3 (a) reveals that the axial stress at failure increased with the increase in the lime content up to a content of $8 \%$. For example, for the bentonite $+2 \%$ lime mix cured for 3 days, the axial stress at failure was $248.25 \mathrm{kPa}$, which increased to $325.25 \mathrm{kPa}, 387.47 \mathrm{kPa}$, and $442.47 \mathrm{kPa}$ and decreased to $311.01 \mathrm{kPa}$ with the increase in the lime content to $4,6,8$ and $10 \%$ respectively. The decrease in the axial stress at failure beyond a lime content of $8 \%$ is attributed to the platy shapes of the unreacted lime particles in the bentonite. These observations are in agreement with Kumar et al. (2007), where the effect of lime on the unconfined compressive strength of black cotton soil was reported.

A similar trend of an increase in the axial stress at failure was observed for the other curing periods of 7, 14 and 28 days as is evident from Fig.3 (a). The axial stress-strain curve of the bentonite $+8 \%$ lime mixture with varying percentages of gypsum and cured for 3,7 , 14, and 28 days respectively is shown in Fig. 3(b). Fig. 3(b) also contains the axial stress-strain curves for the bentonite and bentonite +8 $\%$ lime mixture cured for $3,7,14$ and 28 days respectively.

Fig. 3(b) reveals that the axial stress at failure increased with the increase in the curing period. For example, for the bentonite +8 $\%$ lime $+0.5 \%$ gypsum cured for 3 days, the axial stress at failure was $531.794 \mathrm{kPa}$, which increased to $926.57 \mathrm{kPa}, 1014.95 \mathrm{kPa}$ and $1283.63 \mathrm{kPa}$ with the increase in the curing period to 7,14 and 28 days respectively. The increase in the axial stress at failure with the curing period is attributed to the acceleration in the pozzolanic reactions of the lime with the bentonite in the presence of the gypsum, leading to an increase in the axial stress at failure. A similar trend of an increase in the axial stress at failure was observed for a gypsum content of 1, 2, 4 and $8 \%$.

A close examination of Fig. 3 (b) reveals that the axial stress at failure increased with the increase in the gypsum content up to a content of $4 \%$. For example, for the bentonite $+8 \%$ lime $+0.5 \%$ lime mix cured for 3 days, the axial stress at failure was $531.79 \mathrm{kPa}$, which increased to $573.30 \mathrm{kPa}, 637.18 \mathrm{kPa}$, and $648.73 \mathrm{kPa}$ and decreased to $511.25 \mathrm{kPa}$ with the increase in the gypsum content to $1,2,4$ and $8 \%$ respectively. The decrease in the axial stress at failure beyond a gypsum content of $4 \%$ is perhaps attributed to the platy shapes of the unreacted lime particles in the bentonite even in the presence of the gypsum. A similar trend of an increase in the axial stress at failure was observed for the other curing periods of 7,14 and 28 days as is evident from Fig. 2 (b).

The axial stress-strain behavior of the reference mix reinforced with varying percentages of coir fibers is shown in Fig 3 (c). A study of this figure reveals that the axial stress increased with the increase in the curing period. For example, the axial stress of the reference mix 

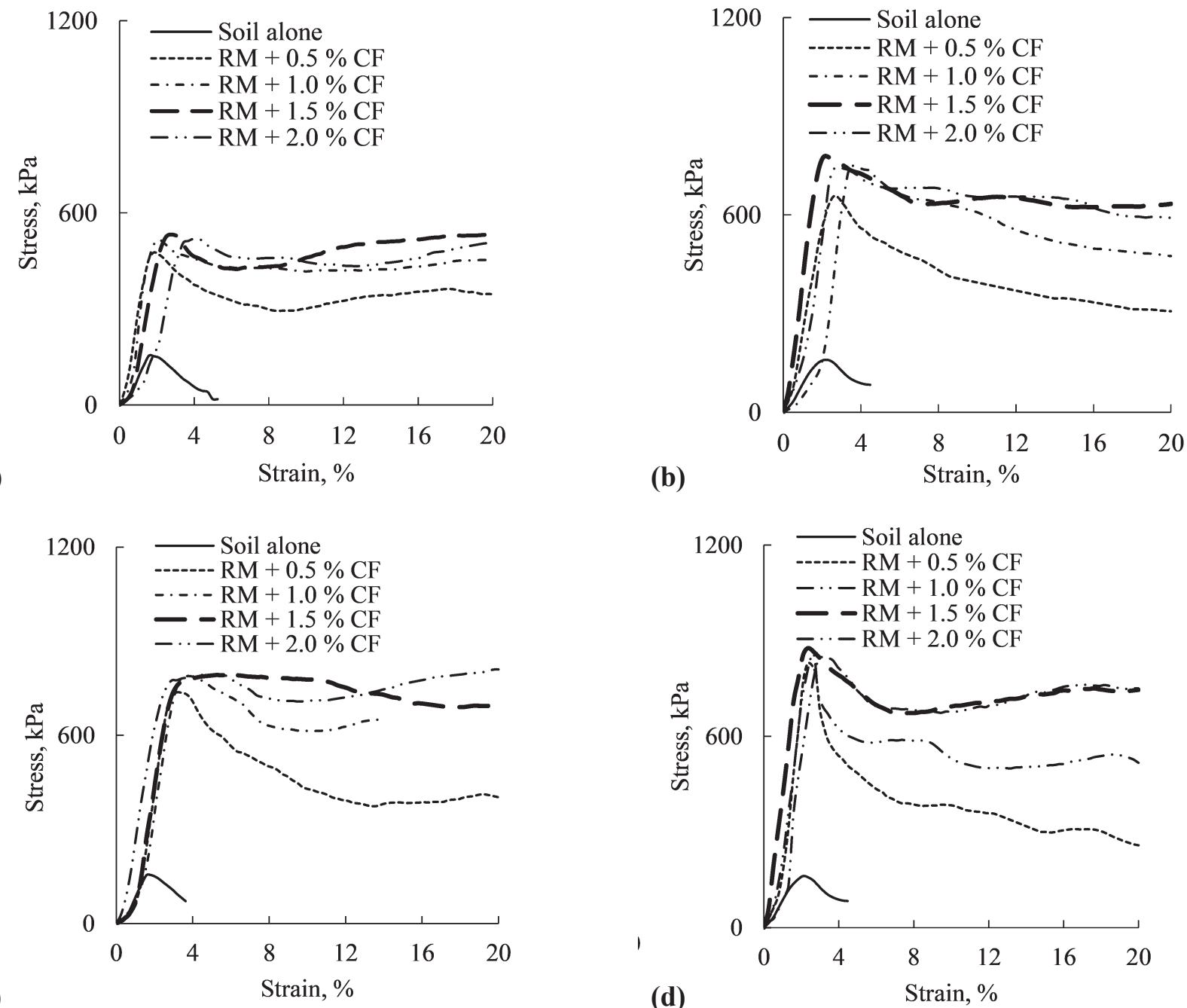

Fig. 3 Variations of unconfined compressive strength for the reference mix mixed with varying percentages of coir fibres at (a) 3 days (b) 7 days (c) 14 days (d) 28 days.

reinforced with $0.5 \%$ coir fibres and cured for 3 days was $476.00 \mathrm{kPa}$, which increased to $658.59 \mathrm{kPa}, 776.93 \mathrm{kPa}$ and $830.81 \mathrm{kPa}$ respectively after 7, 14 and 28 days. A similar trend of an increase in the axial stress at failure was observed for a fibre content of $1,1.5$ and $2 \%$.

A further examination of Fig. 3 (c) reveals that the axial stress at failure increased with the increase in fibre content up to a content of $1.5 \%$. For example, for the reference mix $+0.5 \%$ coir fibre mix cured for 3 days, the axial stress at failure was $476.00 \mathrm{kPa}$, which increased to $516.23 \mathrm{kPa}$ and $531.52 \mathrm{kPa}$ for the 1.0 and $1.5 \%$ coir fibre respectively and decreased to $518.15 \mathrm{kPa}$ with the addition of the 2 $\%$ coir fibre. A similar trend of the axial stress at failure was observed for the other curing periods of 7, 14 and 28 days as is evident from Fig. 3 (c). The increase in the unconfined compressive strength with the addition of the coir fibres up to a fibre content of $1.5 \%$ is attributed to the fact that the cementing gel formed due to the reaction of the bentonite with lime binds the coir fibres with the bentonite particles, leading to an enhancement in the unconfined compressive strength. The decrease in the unconfined compressive strength beyond a fibre content of $1.5 \%$ is attributed to the fact that the formation of lumps of fibres due to excessive adhesion and the poor contact of the fibres with the bentonite particles result in a decrease in the unconfined compressive strength. Thus from the above discussion, it is concluded that the unconfined compressive strength of bentonite does not change with the increase in the curing period. The unconfined com- pressive strength of the reference mix increased with the addition of a coir fibre content of up to $1.5 \%$. Beyond a fibre content of $1.5 \%$, the unconfined compressive strength decreased. However, the unconfined compressive strength of the reference mix-coir fibre composite was less in comparison to the reference mix.

\subsubsection{Post-peak behavior}

To better understand the toughening characteristics of coir fibers in the post - peak region, the stress axis of the stress-strain diagram was normalized with respect to the peak axial stress, and the strain axis was normalized with respect to the strain at the peak axial stress. The variation of the normalized stress-strain curve for the reference mix reinforced with coir fibres is shown in Figs. 4 (a) to (d). An examination of Figs. 4 (a) to (d) reveals that the post - peak behavior of the bentonite-lime-gypsum mixture improved with the addition of the coir fibres to the mix. The variations of the strength ratios at different curing periods with fiber content are shown in Fig. 5. Fig. 5 reveals that the unconfined compression strength of soil reinforced with 1.5 $\%$ coir fibres was about 3.44, 5.04, 5.05 and 5.41 times that of bentonite after $3,7,14$, and 28 day curing periods. Thus, from the above discussion, it is concluded that the post - peak behavior of the bentonite-lime-gypsum improves with the addition of coir fibres. 

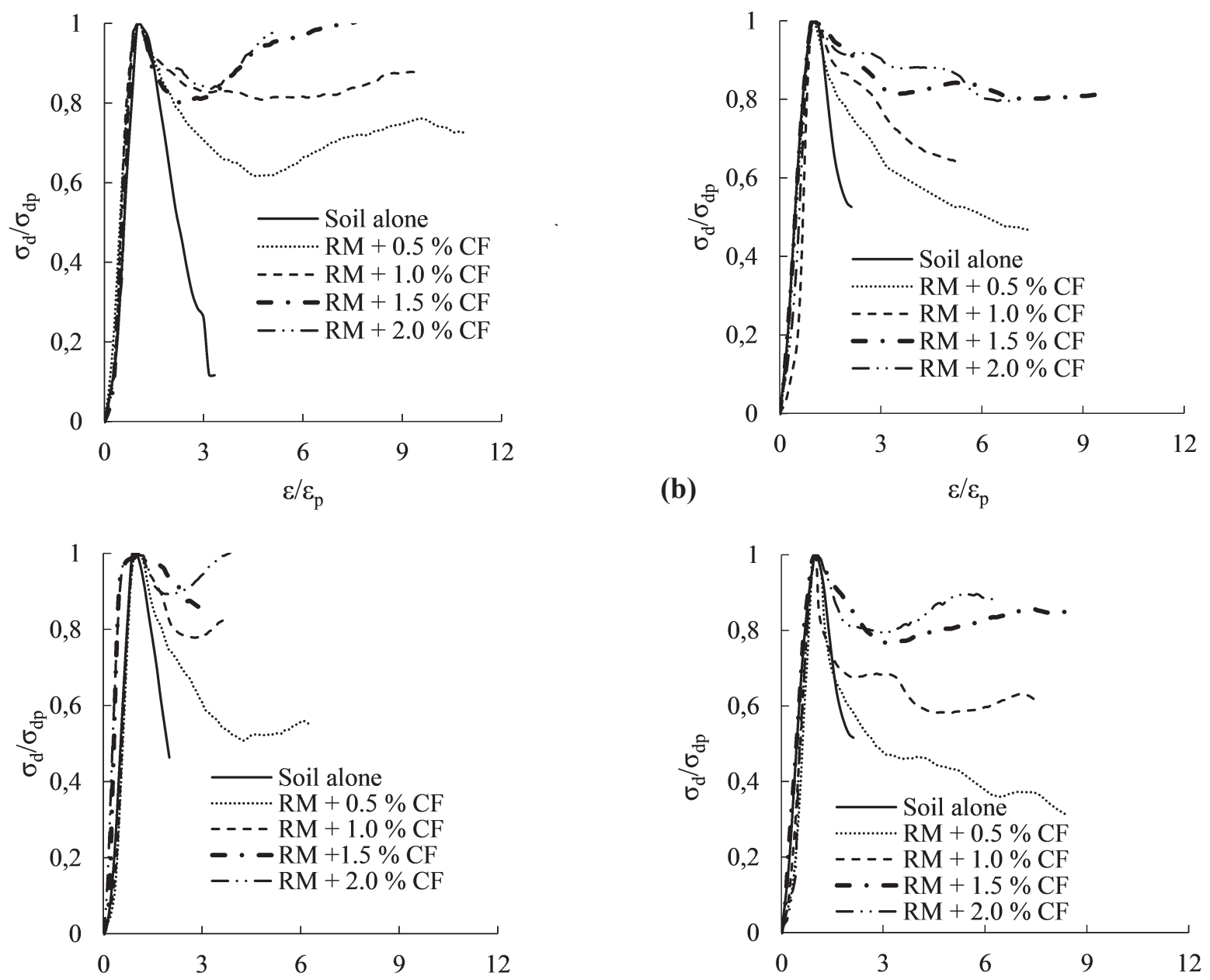

(c)

$$
\varepsilon / \varepsilon_{\mathrm{p}}
$$

$$
\varepsilon / \varepsilon_{\mathrm{p}}
$$

Fig. 4 Normalized stress-strain curves for the reference mix mixed with varying percentages of coir fibres at (a) 3 days (b) 7 days (c) 14 days (d) 28 days.

Further, Schurholz (1991) reported the durability of coir geotextiles. According to Schurholz, coir geotextiles retain $20 \%$ of their original tensile strength after one year in incubator tests with high fertile soil. He further observed that when natural fabrics were put in a shower room and kept wet for 167 days in conditions to simulate the traction effect while flooding, the coir sustained almost no damage. While studying the performance of a model retaining wall reinforced with coir ropes, Sarsby et al. (1992) reported that the loss in strength of the coir rope after 10 months in pulverized ash was $20 \%$. Balan (1995) reported that coir degrades at a faster rate in sand with a high organic content followed by clay with a high organic content and, finally, saturated soft clay, where the degradation is the least. He further reported that the overall life of coir is more than two-three years, and brown coir degrades (about $20 \%$ in seven months) at a faster rate than white coir (about $10 \%$ in seven months). Thus the coir fibres in the bentonite-lime-gypsum matrix may satisfy the durability requirement for temporary roads. However further research is needed to verify this. The authors of this paper are of the opinion that the use of this composite material can be more economical in those areas where these materials are available in nearby locations.

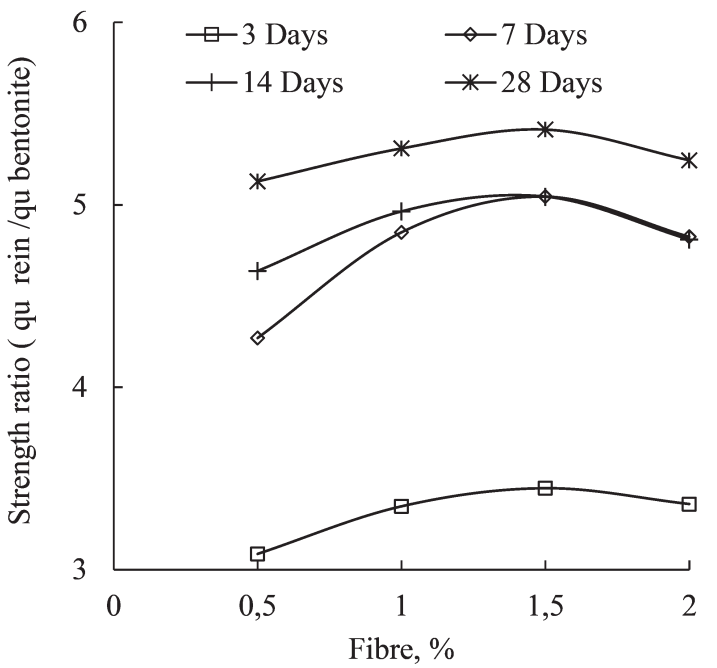

Fig. 5 Variations of normalized unconfined compression strength with a coir fibre content at different curing periods. 


\section{CONCLUSION}

An experimental study was carried out to investigate the effect of coir fibres on the compaction and unconfined compressive strength of bentonite stabilized with lime-gypsum. The study resulted in the following conclusions.

1. The dry unit weight and the optimum moisture content of the bentonite-lime mix increased with the addition of gypsum.

2. The dry unit weight of the reference mix decreased, and the optimum moisture content increased with the addition of coir fibre.

3. The unconfined compressive strength of the bentonite increased with the increase in the lime content up to $8 \%$. Beyond $8 \%$, the unconfined compressive strength decreased.

4. The unconfined compressive strength of the bentonite $+8 \%$ lime increased up to $4 \%$ gypsum. Beyond $4 \%$, the unconfined compressive strength decreased.

5. The unconfined compressive strength of the reference mix increased with the addition of coir fibre up to a fibre content of $1.5 \%$. The trend was reversed after that. The unconfined compressive strength of the reference mix-coir fibre composite was less in comparison to the reference mix.

6. The unconfined compressive strength of bentonite increased with the addition of lime and gypsum and with an increase in the curing period.

7. The improvement in the post - peak region was better for the reference mix of reinforced coir fibers as compared to the unreinforced reference mix.

8. The optimum value of the lime content, gypsum content, and coir fibre content in bentonite- lime-gypsum-coir fibre mixtures may be taken as $8 \%, 4 \%$ and $1.5 \%$, respectively.

On the whole, this study has attempted to provide an insight into the compaction and unconfined compressive strength of bentonite stabilized with lime and gypsum reinforced with coir fibre. The improved post - peak behavior of the bentonite-lime-gypsum-coir fibre mixture will boost the construction of temporary roads on such problematic soils. Further, its use will also provide an environmental motivation for providing a means of consuming large quantities of coir fibres.

\section{NOTATION}

$\mathrm{B}=$ Bentonite
$\mathrm{L}=$ Lime
$\mathrm{G}=$ Gypsum
$\mathrm{CF}=$ Coir Fibre
$\mathrm{RM}=$ Reference mix, $\mathrm{B}+8 \% \mathrm{~L}+4 \% \mathrm{G}$ 


\section{REFERENCES}

Al-Wahab, R. M. - El-Kedrah, M. M. (1995) Using fibres to reduce tension cracks and shrink/swell in compacted clays. Geoenvironment 2000, Geotechnical Special Publication No. 46, Y. B. Acar and D. E. Daniel, eds., ASCE, Reston, Va, 1: 791-805.

Andersland, O. B. - Khattak, A. S. (1979) Shear strength of kaolinite/fibre soil mixtures. In: Proceedings of Int. Conf. on Soil Reinforcement, Paris, France, 1: 11-16.

Babu, G. L. S. - Vasudevan, A. K. (2008) Strength and stiffness response of coir fibre-reinforced tropical soil. Journal of Materials in Civil Engineering, 20 (9): 571-577.

Balan, K. (1995) Studies on engineering behavior and uses of geotextiles with natural fibers. Unpublished Ph.D Thesis submitted to Indian Institute of Technology Delhi (India).

Banerjee, P. K. - Chattopadhyay, R. - Guha, A. (2002) Investigations into homogeneity of coir fibres. Indian Journal of Fibre and Textile Research, 27: 111-116.

Casagrande, M. D. T. - Coop, M. R. - Consoli, N. C. (2006) Behaviour of a fibre reinforced bentonite at large shear displacements. Journal of Geotechnical and Geoenvironmental Engineering, 132 (11): 1505-1508.

Dasaka, S. M. - Sumesh, K. S. (2011) Effect of coir fibre on the stress-strain behavior of a reconstituted fine- grained soil. Journal of Natural Fibres, 8(3), 189-204.

Dutta, R. K. - Khatri, V. N. - Gayathri, V. (2012) Effect of addition of treated coir fibres on the compression behaviour of clay. Jordan Journal of Civil Engineering, 6(4), 476-488.

Dutta R. K. - Khatri V. N. - Gayathri, V. (2013) Effect of treated coir fibre on the compaction and CBR behaviour of clay. International Journal of Geotechnics and Environment, 5(1), 19-33.

Feuerharmel, M. R. (2000) Analysis of the behaviour of polypropylene fibre-reinforced soils. MSc Dissertation, Federal Univ. of Rio Grande do Sul, Porto Alegre.

Hejazi, S. M. - Sheikhzadeh, M. - Abtahi, S. M. - Zadhoush, A. (2012) A simple review of soil reinforcement by using natural and synthetic fibres. Construction and Building Materials, 30, 100-116.

Hoare, D. J. (1979) Laboratory study of granular soils reinforced with randomly oriented discrete fibres. Int. Conference on Use of Fabrics in Geotech, Vol.1, Paris, 47-52.

IS: 2720, Part III (1980) Determination of specific gravity. Indian Standard methods of test for soils. Bureau of Indian Standards, New Delhi, 1-8.

IS: 2720, Part X (1991) Determination of unconfined compressive strength. Indian Standard methods of test for soils. Bureau of Indian Standards, New Delhi, 1-4.

Kumar, A. - Walia, B. S. - Abjaj, A. (2007) Influence of fly ash, lime, and polyester fibres on compaction and strength properties of expansive soil. J. Mater. Civ. Eng., 19(3), 242-248.

Kumar, S. - Tabor, E. (2003) Strength characteristics of silty clay reinforced with randomly oriented nylon fibres. Electronic Journal of Geotechnical Engineering, 8 (B).
Lekha, K. R. - Sreedevi, B. G. (2006) Coir fibre for the stabilisation of weak subgrade soils. Highway Engineering Lab, NATPAC, Thiruvananthapuram.

Maher, M. H. - Ho, Y. C. (1994) Mechanical properties of kaolinite/ fibre soil composite. Journal of Geotechnical and Geoenvironmental Engineering, 120 (8): 1381-1393.

Michlowski, R. L. - Cermak, J. (2003) Triaxial compression of sand reinforced with fibres. Journal of Geotechnical and Geoenvironmental Engineering, 129(2), 125-136.

Mwasha, P. A. (2009) Coir fibre: a sustainable engineering material for the Caribbean environment. The College of the Bahamas Research Journal, 15: 36-44.

Nataraj, M. S. - McManis, K. L. (1997) Strength and deformation properties of soils reinforced with fibrillated fibres. Geosynthetic International, 4 (1): 65-79.

Prasad, S. V. - Paviandthran, C. - Rohatgi, P. K. (1983) Alkali treatment for coir fibres for coir-polyester composites. Research Regional Laboratory, pp. 1443-1454.

Ramesh, H. N. - Manoj Krishna K. V. - Mamatha H. V. (2010) Compaction and behaviour of lime coir fibre treated black cotton soil. Geomechanics and Engineering-An International Journal, 2(1), 19-28.

Ranjan, G. - Vasan, R. M. - Charan, H. D. (1994) Behaviour of plastic fibre reinforced sand. Geotextiles and Geomembranes, 13, 555-565.

Rao, G. V. - Balan, K. (2000) Coir geotextiles-emerging trends. Kerala State Coir Corporation Limited, Alappuzha, Kerala.

Sarsby, R. W. - Ali, M. - DeAluis, R. - Khoffot, J. H - Medongall, J. M. (1992) Low cost soil reinforcement for developing countries. Proceedings of Int. Conf. on Non-Wovens, The Textile Institute, North India Section, pp. 297-310.

Saran, S. (2006) Text book of Reinforced soil and its engineering applications. I. K. International Pvt. Ltd. New Delhi.

Schurholz, H (1991) Use of woven coir geotextiles in Europe. Coir, $35(2), 18-25$.

Sebastian, B. - Cryus, S. - Jose, B. T. (2011) Effect of inclusion of coir fibre on the shear strength of marine clay. Proceedings of Indian Geotechnical Conference, Dec. 15-17, Kochi, India.

Wild, S. - Kinuthia, J. M. - Robinson, R. B. - Humphreys, I. (1996) Effects of ground granulated blast furnace slag (GGBS) on the strength and swelling properties of lime-stabilized kaolinite in the presence of sulphates. Clay Minerals, 31, 423-433.

Zeigler, S. - Leshchinsky, H. I. L. - Perry, E. D. (1998) Effect of short polymeric fibres on crack development in clays. Soils and Foundation, 38 (1): 247-253. 